\title{
IDENTIFICATION OF POOR GROUND WITH THE AID OF DC-RESISTIVITY: RESULTS FROM WORK ON THE ÖRESUND BRIDGE CONNECTIONS
}

\author{
Christian Bernstone and Torleif Dahlin \\ Dept. of Geotechnology, Lund University, Box 1 18, S-221 00 Lund, Sweden \\ Lars Bjulemar and Jörgen Brorsson \\ B\&B Geofysik AB, Box 4528, S-203 20 Malmö, Sweden
}

\section{INTRODUCTION}

Together with large investments in the connecting land infrastructure the construction of the $16 \mathrm{~km}$-long coast to coast Öresund link between Copenhagen and Malmö is now underway. Construction works were initiated in 1994 and the link is scheduled to be inaugurated around the year 2000. The Swedish abutment is being built on Lernacken to the south of Malmö (Figure 1).

SVEDAB AB, owned by the Swedish state, are investing 2.0 billion SEK in road and railway extensions in the Lernacken area. The shared road and railway corridor will extend in a 15 meter deep cutting in the near-coast area and thereafter continue on earth embankments (Möller 1993).

The terrain of the Lernacken area is relatively propitious, with a gentle topography. Despite that extensive excavations (2-3 billion $\mathrm{m}^{3}$ ) are required (J\&W 1994). The area is an in-filled beach zone by leftovers from a nearby lime quarry. About 10 percent of the fill have less good properties from a geotechnical point of view, e.g., sludge and ash (J\&W 1994). Apart from excavations and decontamination work, ground reinforcements were performed by drop weight compaction to achieve competent ground. As a mean of quality assurance follow-up in-situ studies were required, i.e., to control that no large volumes of waste or contaminated earth were left. This was established by a resistivity survey and a thermographic survey.

It is sometimes claimed that overoptimistic geophysicists and use of inappropriate methods hinders acceptance of geophysical surveys in civil engineering (e.g., McCann and Culshaw 1996). However, good experience of DC resistivity in a survey of sludge ponds at Lernacken (Bernstone and Dahlin 1997) made an additional survey interesting. In total 6 kilometers of profiling were performed along the railway and road extensions with the main objective to identify and delineate the extent of potential waste leftovers both in plane and depth.

\section{GEOLOGY}

Below the fill the Quarternary cover varies in thickness between 2-15 meters, and is composed mainly of clay tills and stratified interglacial sediments. The upper bedrock in the region is a Tertiary limestone overlain by a sheet of glacial till, which follows the slightly undulating limestone relief. The transition to harder limestone is often diffuse, passing through a layer of eroded limestone. 


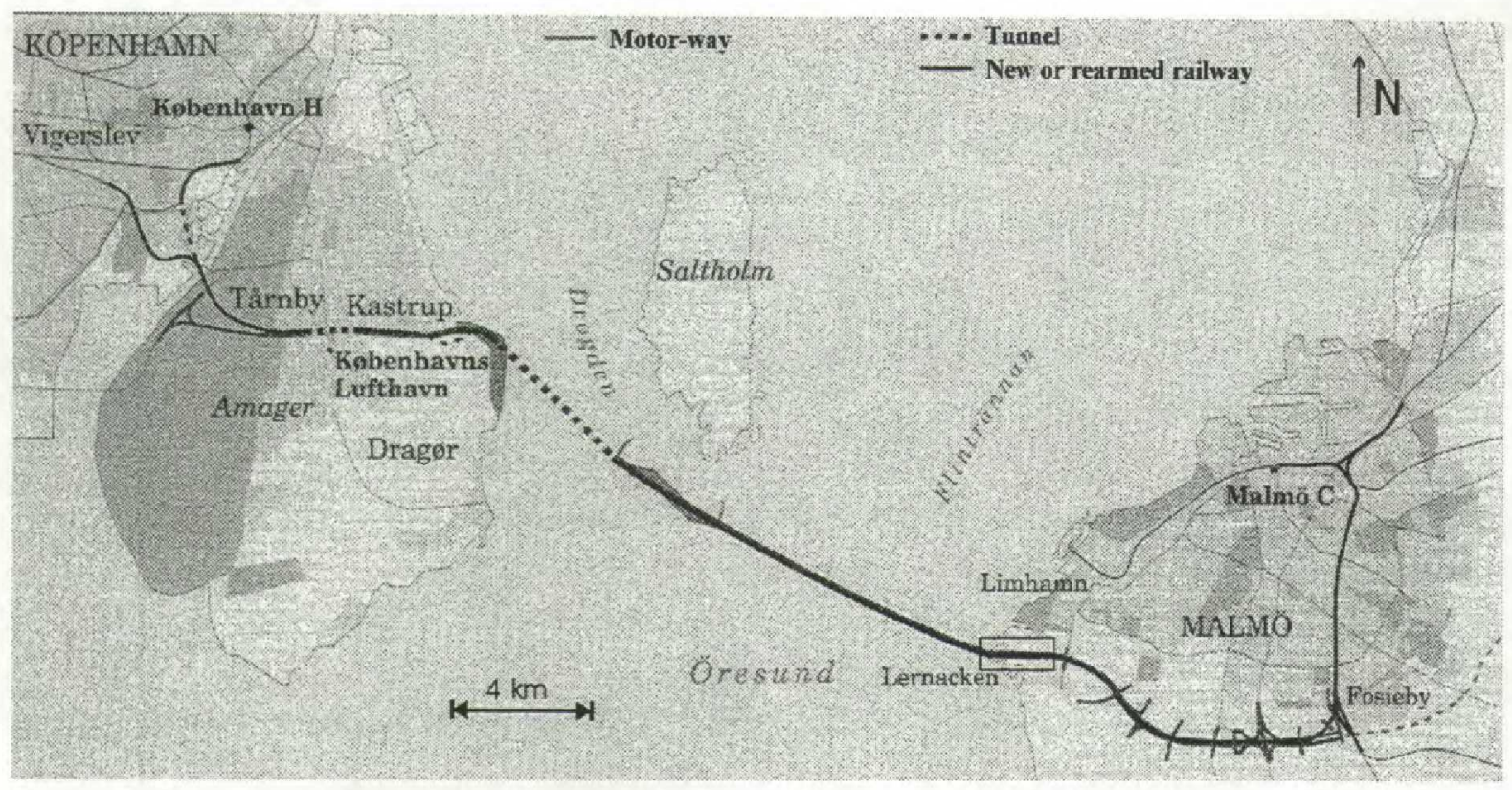

Figure 1. Situation plan of the Öresund link (modified from NE 1996).

\section{GEOPHYSICAL DATA ACQUISITION AND DATA PROCESSING}

The resistivity data acquisition system used in this survey was the ABEM Lund Imaging System (Dahlin 1996). The system supports measurements according to a roll-along principle. The equipment was operated by two people and the Wenner configuration was used throughout the surveys (September 1996 and January 1997). The measurement protocol included 10 different electrode spacings, ranging between 5-120 meters.

Modelling tests (Dahlin and Loke 1997) have shown that the CVES technique using Wenner array works rather well, even in the case of large 3D variations. The $2 \mathrm{D}$ inversion routine used (RES2DINV) is based on the generation of a finite difference (FD) model of the subsurface. The model resistivities of the FD grid are automatically adjusted through an iterative process so that the model response converges towards the measured data (Loke and Barker 1996).

\section{THERMAL AND GEOTECHNICAL DATA}

A thermal activity survey was done in April 1997 by SVEDAB. Thermography is a technique for detecting and measuring variations in the heat emitted by various regions of the ground. In this survey the measured temperatures that exceeded the normal situation were divided into three categories. However, along the road and railway corridor the measured temperatures fell below the lowest category (J\&W 1997).

Only a few of the drillings in earlier geotechnical surveys coincide with the low resistivity anomaly zones. There are, however, information from several shallow test pits available.

\section{RESULTS AND DISCUSSION}

The map of Figure 2 show the area covered by the resistivity survey. One of the inverted 2D profiles is shown in Figure 3a. The inverted profiles were merged together into a quasi-3D model. Figure $3 \mathrm{~b}$ show two depth slices (out of eight) with the surveyed lines superimposed.

Several well defined low resistivity structures (1-16 $\Omega \mathrm{m}$ ) are seen in Figure $3 \mathrm{a}$ and $3 \mathrm{~b}$. In most cases these zones coincide with areas where filter ash has been mapped earlier (see 
Figure 2). The pits and the few drillings show that the corresponding material have a silty character mainly composed of filter ash (remainders from cement production).

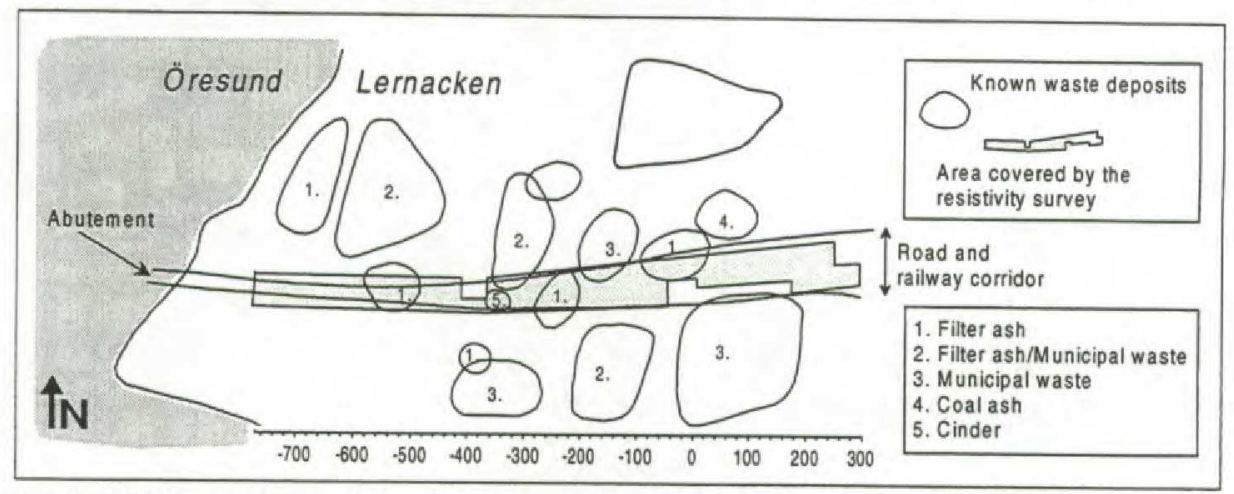

Figure 2. A principle outline of the surveyed area (modified from J\&W 1997).

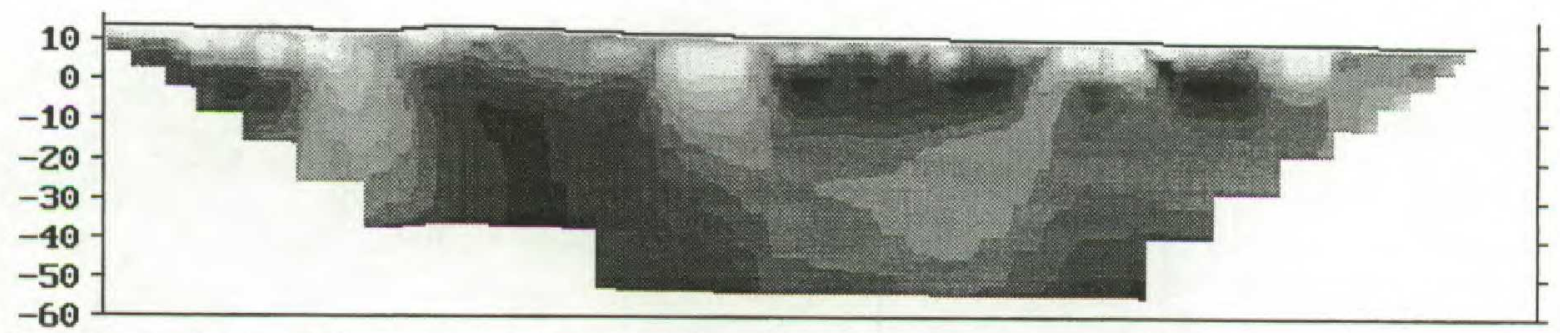

Figure 3a. One of the inverted 2D sections (see arrow below; $-350-+260 \mathrm{~m}$.). The model misfit (rms residual) is $7.3 \%$. For color scale see Figure $3 b$.
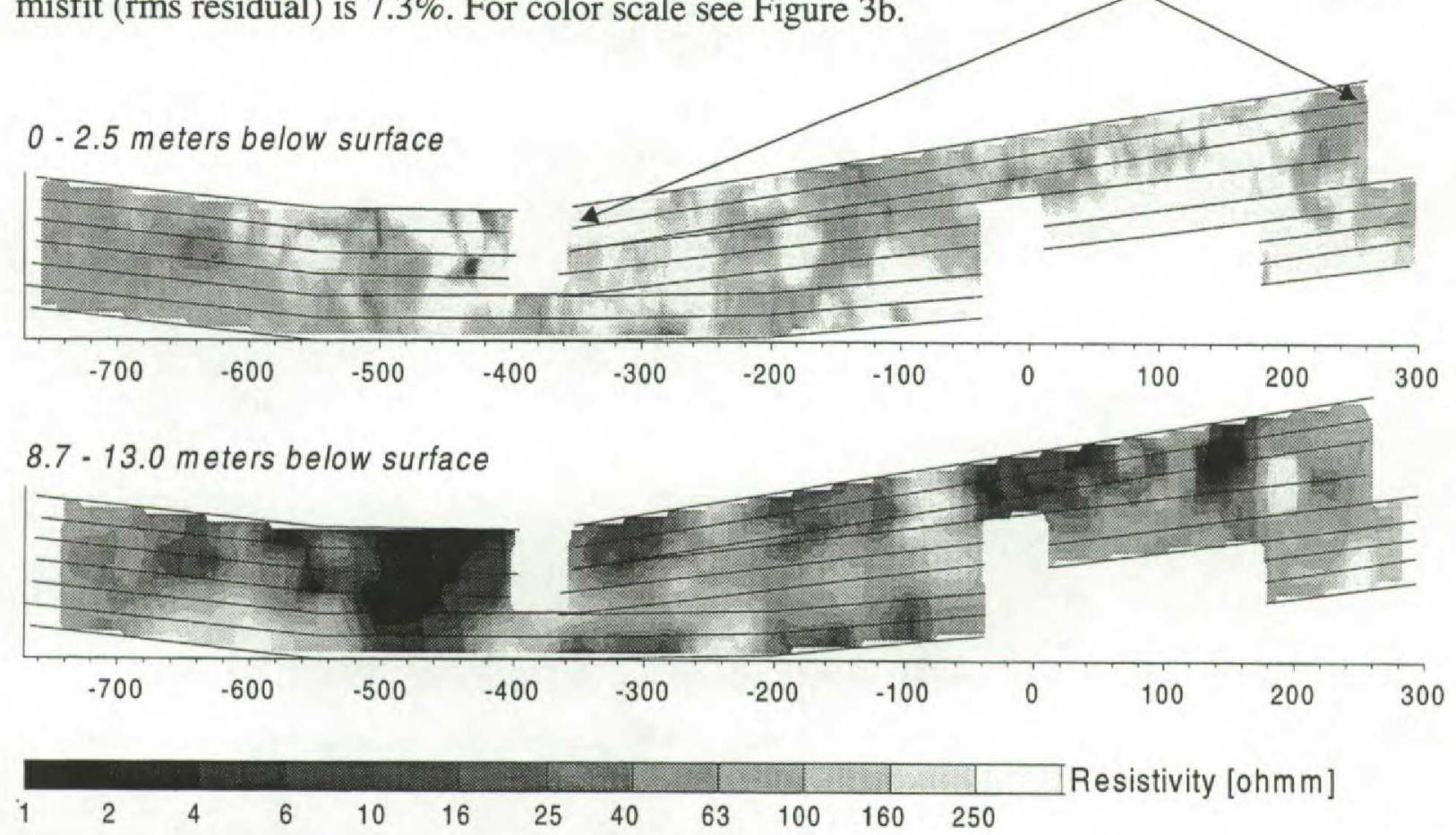

Figure $3 \mathrm{~b}$. Depth slices of merged 2D inverted resistivity profiles (level 0-2.5 m. and 8.7$13.0 \mathrm{~m}$. below surface). The equivalent profiles have been superimposed (separation $10 \mathrm{~m}$.)

The west part of the surveyed area has in-fills of mainly clay tills. In this area we also find a low resistive structure (Figure $3 \mathrm{~b},-650 \mathrm{~m}$.). However, no known waste has been documented in earlier investigations (J\&W 1997). Because the clay till has a relatively high resistivity $(\approx 60$ $\Omega \mathrm{m}$ ), and because ash deposits are found close to the north, there are reasons to suspect that the low resistivities are due to presence of ash. The low resistivities at +150 meters (Figure $3 b$ ) is 
probably also due to an ash deposit (this is indicated by nearby excavations, J\&W 1997). The ash deposit mapped at -250 meters in Figure 2 is not fully detectable by the resistivity (Figure 3b). Low resistivities, however, are found somewhat further to the east and one explanation to this location misfit could be a difficulty to accurate delineate it in earlier surveys.

The thermographic survey did not reveal any elevated temperatures along the road and railway corridor. However, thermal anomalies were detected in the areas of known municipal waste deposits (J\&W 1997). The conclusion is therefore that no deposits of organic material remain along the road and railway corridor.

The ash deposits have relatively low contaminant levels, mainly metals (J\&W 1997), and the geotechnical properties are satisfying. The ash will therefore not be excavated.

\section{CONCLUSIONS}

The described case study has shown that DC-resistivity can be a powerful tool for locating and mapping buried waste. The survey succeeded to distinguish filter ash from clay tills and lime quarry waste.

Based on the results from the resistivity survey, together with the survey of thermal activity, it is concluded that no organic waste exist in the in-fill of the surveyed road and railway corridor. The good survey results add to our experience in recent years of the capability of DC resistivity multi-electrode surveys to successfully locate conductive waste.

\section{ACKNOWLEDGMENT}

The authors thank AFN (Swedish Waste Research Council) for their financial support for the work carried out for this paper. We thank $\AA$ se Borgkvist at J\&W AB and SVEDAB for their fruitful cooperation.

\section{REFERENCES}

Bernstone, C. and Dahlin, T. (1997). Electromagnetic and DC resistivity mapping of waste deposits and industrial sites - experiences from southern Sweden, European Journal of Engineering and Environmental Geophysics. (In press).

Dahlin, T. (1996). 2D resistivity surveying for environmental and engineering applications, First Break, v. 14, no. 7, p. 275-283.

Dahlin, T and Loke, M. H.. (1997). Quasi-3D resistivity imaging - mapping of three dimensional structures using two dimensional DC resistivity techniques, Procs. 3rd Meeting Environmental and Engineering Geophysics, Aarhus, 8-11 September 1996, This volume.

J\&W (1994). Öresundsförbindelsen, Svenska anslutningar, Lemacken: Kompletterande anläggnings- och miljögeotekniska unders. för arbetsplan, Del 1, SVEDAB 1994-03-25, 97 p.

J\&W (1997). Sammanställning och tolkning av resistivitetsmätningar och termografering, SVEDAB 1997-06-05, $6 \mathrm{p}$.

Loke, M. H. and Barker, R. D. (1996). Rapid Least-Squares Inversion of Apparent Resistivity Pseudosections by a Quasi-Newton Method, Geophysical Prospecting, v. 44, no. 1, p. 131-152.

McCann, D., and Culshaw, M. (1996). Talking point, Ground Engineering, v. 29, no. 4, p.3.

Möller, C. (1993). Öresundsförbindelsens svenska landanslutningar: järnväg och motorväg i gemensam korridor, V-byggaren, No. 3, pp. 10-12.

NE (1996). Nationalencyklopedin, ISBN 91-7024-620-3, v. 20, p. 458. 